\title{
Toplumsal Cinsiyet Eşitliği Dersini Alan ve Almayan Üniversite Öğrencilerinin Toplumsal Cinsiyet Rollerine İlişkin Tutumları
}

\section{The Gender Attitude Related Rolles of University Students Who Continued or Not the Gender Equality Course}

\author{
Nuray EGELIOĞLU CETIŞLi' ${ }^{1}$ Ekin Dila TOP², Gülşen IŞIK³
}

İletişim/ Correspondence: Nuray EGELİOĞLU CETİşLİ Adres/ Address: İzmir Katip Çelebi Üniversitesi Sağlık Bilimleri Fakültesi Hemşirelik Bölümü Doğum ve Kadın Hastalıkları Hemşireliği AD., İzmir, Tel: 02323293535 Fax: 02323253357 E-mail: nurayegelioglu@hotmail.com

$\ddot{O} Z$

Amaç: Çalı̧̧ma, toplumsal cinsiyet eşitliği dersini alan ve almayan üniversite öğrencilerinin toplumsal cinsiyet rollerine ilişskin tutumlarını belirlemek amacıyla gerçekleştirildi.

Yöntem: Tanımlayıcı ve karşılaştırmalı tipte planlanan bu çalışma, toplumsal cinsiyet eşitliğine ilişkin dersi alan ve almayan toplam 84 hemşirelik bölümü dördüncü sinıf ögrencisi ile yürütüldü. Verilerin toplanmasında Birey Tanitım Formu ve Toplumsal Cinsiyet Rolleri Tutum Ölçeği kullanıldı. Verilerin değerlendirilmesi tanımlayıcı testler, ki kare, Mann-Whitney U, KruskalWallis ve Wilcoxon testi ile yapuldl.

Bulgular: Çalışmada eğitim alan ve almayan gruptaki öğrencilerin birinci izlemde Toplumsal Cinsiyet Rolleri Tutum Ölçeği puan ortalamaları arasında fark bulunmazken, eğitim sonrasında yapılan ikinci izlemde gruplar arasındaki puan farkinin istatistiksel olarak anlamlı olduğu belirlendi.

Sonuç: Çalı̧̧madan elde edilen sonuçlar Toplumsal Cinsiyet Eşitliği dersinin öğrencilerin toplumsal cinsiyet rol tutumları üzerine etki ettiğini göstermektedir. Bu nedenle tüm yüksekögretim kurumlarinda Toplumsal Cinsiyet Eşitliği dersine müfredatlarda yer verilmesi önerilmektedir.

Anahtar Kelimeler: Toplumsal cinsiyet rolleri, planlı eğitim, hemşirelik öğrencisi.

\section{ABSTRACT}

Aim: This study is conducted to determine the gender attitude related rolles of university students who continued or not the gender equality course.

Method: A descriptive and comparative study is planned in this study. It is conducted with 84 students that all take and not take the lecture of gender equility and. Data were collected by using personal identity form and Gender Roles Attitude Scale. The analysis of data made by descriptive tests chi-square, Mann-Whitney U, Kruskal-Wallis and Wilcoxon.

Results: At the first monitor, no difference found between the groups that had the education and that didn't have the education regarding the Gender Roles Attitude Scale score average. But at the second monitor made after the education, a statistically meaningful difference found on score averages of groups.

Conclusion: The results of the study shows that the lecture of Gender Equility effects gender roles attitude of students and it is suggested that this lecture should be included in the curriculum of all higher education institutions.

Keywords: Gender roles, planned education, nursing student.

\footnotetext{
${ }^{l}$ Yrd. Doç. Dr. İzmir Katip Çelebi Üniversitesi Sağlık Bilimleri Fakültesi Hemşirelik Bölümü, İzmir/ TURKEY, ${ }^{2}$ Öğr.Gör. İzmir Katip Çelebi Üniversitesi Hemşirelik Bölümü, İzmir/ TURKEY, ${ }^{3}$ Arş. Gör. İzmir Katip Çelebi Üniversitesi Sağllk Bilimleri Fakültesi Hemşirelik Bölümü. İzmir/ TURKEY

Yazının gönderilme tarihi: 26.01.2016

Yazının basım için kabul tarihi: 26.04.2017

doi: $10.17672 /$ fnhd.07668
} 


\section{GíRiş}

Cinsiyet kavramı, dünya üzerindeki bütün insanları kadın ve erkek olmak üzere iki gruba ayırır. Kişileri gruplaştırmak ve farklılaştırmak için kullanılan ölçütlerden birisi, belki de birincisi cinsiyettir (Akın ve Demirel 2003; Demir 1999).

Bir toplumun kültürü, kadın ve erkek davranışları ile ilgili nasıl davranacakları, nasıl düşünecekleri ve toplum içinde ne şekilde aktivite gösterecekleri gibi cinsiyet kalıpları ile ilgili normları ve beklentileri içerir. Kadın ve erkeklerin davranışsal özellikleri önceden belirlenmiş biyolojik örüntüler olmaktan çok öğrenilmiş davranış örüntüleridir ve toplumdaki işlevleri, sorumlulukları, hakları, kişilik özellikleri toplumsal cinsiyete göre şekillendirilmektedir (Özvarış 2007; Vefikuluçay ve ark. 2007; Y1lmaz ve ark. 2009; Zeyneloğlu ve Terzioğlu 2011).

Türkiye gibi ataerkil toplumlarda toplumsal cinsiyet rolleri kadın ve erkeklerin yaşamını farklı yönlerde şekillendirmektedir. Toplum tarafindan kadına çocuk dogurma ve büyütme, temizlik yapma, yemek pişirme gibi ev işlerinden sorumlu olma, iş hayatında aktif olmama gibi roller yüklenirken; erkeklere evin geçiminden sorumlu olma, parasal kaynaklar üzerinde kontrol sahibi olma ve evin reisi olma gibi roller yüklenmektedir (Atış 2010; Bhasin 2003; Dökmen 2004; Özvarış 2008; Vefikuluçay ve ark. 2007; Zeyneloğlu ve Terzioğlu 2011).

Toplumda kadının ikinci plana atılmasına neden olan bu roller, cinsiyetler arasında da eşitsizliğe neden olmaktadır. Toplumsal cinsiyet eşitliği, kadınlarla erkeklerin kanunlar ve politikalar açısından eşit olmaları; aileler, topluluklar ve genel olarak toplum içinde kaynaklara ve hizmetlere eşit erişime sahip olmalarıdır (Akın ve Demirel 2003; Yılmaz ve ark. 2009). Dünya Ekonomik Forumu'nun yayınladığı Cinsiyet Ayrımcılığı Raporu, ülkeleri; ekonomik katılım ve firsatlar, eğitime erişim, siyasal katılım, sağlık hakkı gibi farklı alanlarda değerlendirerek dünyadaki kadın-erkek eşitsizliğini ortaya koymaktadır. Bu raporun sonucuna göre, 2015 yılında Türkiye 145 ülke arasında 130. sirada yer almakta ve dünyada toplumsal cinsiyet uçurumunun en derin ol- duğu ülkelerden biridir (World Economic Forum The Global Gender Gap Report 2015). Eşitsizliği ortaya çıkaran en önemli faktörlerden biri, erkeklerin toplumsal cinsiyet rollerine ilişkin geleneksel bakış açılarıdır (Akın ve Demirel 2003; Yılmaz ve ark. 2009). Geleneksel rollerin değişimi ve bilinçlenmenin oluşabilmesi için eğitim faaliyetlerinin düzenlenmesi gerekmektedir (Özcan 2012; Sağ 2003; Turan ve ark. 2011).

Toplumsal cinsiyet eğitimi, toplumsal cinsiyet bilincini kazandırarak, toplumsal cinsiyet rollerini oluşturan kalıp yargıların olumsuz etkilerini fark edip eşitsizliklerin giderilmesini hedeflemektedir (Flowers 2009). Yetişkinliğe geçiş dönemi olan gençlik çağı, bireyi biyolojik, psikolojik ve sosyal yönden olgunluğa hazırlayan önemli bir dönemdir (Demir 1999). Toplumsal cinsiyet bakış açısı ve algılama biçimlerinin değiştiği bu geçiş döneminde eğitim faaliyetlerinin gençlere yönelik olması ile bir sonraki kuşağa, cinsiyet rolü öğretisi daha eşitlikçi olarak aktarılacaktır. Üniversitelerde temel mesleki eğitimin yanı sıra toplumsal cinsiyet eşitliği konusunda farkındalığın kazandırılması da önemlidir (Demir 1999; Keith ve Jacqueline 2002; Pınar, Taşkın ve Eroğlu 2008). Çalışma, toplumsal cinsiyet eşitliği dersini alan ve almayan üniversite öğrencilerinin toplumsal cinsiyet rollerine ilişkin tutumlarını belirlemek amacıyla gerçekleştirildi.

\section{YÖNTEM}

\section{Araştırmanın Tipi}

$\mathrm{Bu}$ çalışma tanımlayıcı ve karşılaştırmalı tipte planland1 ve uyguland1.

\section{Araştırmanın Evreni ve Örneklemi}

Araştırmanın Türkiye'nin batısında yer alan bir devlet üniversitesinde, Toplumsal Cinsiyet Eşitliği dersini alan öğrencilerle yapılması hedeflenmiştir. Fakat Toplumsal Cinsiyet Eşitliği dersi üniversitede sadece hemşirelik bölümünde verilmektedir. Bu nedenle çalışma hemşirelik bölümü dördüncü sınıf öğrencileri ile (N= 103) 23 Şubat 2015-5 Haziran 2015 tarihleri arasında iki grupta yürütülmüştür. Birinci grupta (eğitim grubu) Toplumsal Cinsiyet Eşitliği dersi alan ve araştırmaya katılmayı kabul eden öğrenciler $(n=44)$, ikinci grup- 
ta ise eğitim almayan ve araştırmaya katılmayı kabul eden öğrenciler $(n=40)$ yer almaktadır. Araştırmada gruplar cinsiyet açısından homojenize edilmiştir.

\section{Veri Toplama Araçları ve Verilerin Toplanması}

Araştırmada verileri toplamak amacıyla Birey Tanıtım Formu ve Toplumsal Cinsiyet Rolleri Tutum Ölçeği kullanılmıştır.

Birey Tanıtım Formu: Bu formda, öğrencilerin sosyodemografik özelliklerine ilişkin literatür taranarak araştırmacılar tarafından oluşturulan 8 soru yer almaktadır (Aksan ve ark. 2011; Öngen ve Aytaç 2013; Özcan 2012; Sağ 2003; Turan ve ark. 2011; Vefikuluçay ve ark. 2007; Y1lmaz ve ark. 2009).

\section{Toplumsal Cinsiyet Rolleri Tutum Ölçeği (TCRTÖ):}

Ölçek, Zeyneloğlu ve Terzioğlu (2011) tarafindan geliştirilmiş ve bireylerin toplumsal cinsiyet rollerine ilişkin tutumlarını belirlemektedir. Ölçek, eşitlikçi cinsiyet rolü, kadın cinsiyet rolü, evlilikte cinsiyet rolü ve geleneksel cinsiyet rolü ve erkek cinsiyet rolü olmak üzere beş alt boyuttan ve 38 maddeden oluşan 5'li likert tipi bir ölçektir. Ölçekten alınabilecek en yüksek puan 190 iken, en düşük puan ise 38'dir ve alınan puanın artması, öğrencinin toplumsal cinsiyet rollerine ilişkin 'eşitlikçi tutuma sahip' olduğunu, en düşük değer ise öğrencinin toplumsal cinsiyet rollerine ilişkin 'geleneksel tutuma sahip' olduğunu göstermektedir. Zeyneloğlu ve Terzioğlu (2011) tarafindan ölçeğin Cronbach alpha değeri .92 olarak bulunmuştur. Araştırmada ise, Cronbach alpha değeri .88 olarak bulunmuştur.

Hemşirelik bölümü dördüncü sınıf öğrencileri ile iki grupta yürütülen çalışmada ilk hafta çalışmanın amacı anlatılmış ve araştırmaya katılmayı kabul eden öğrencilere Birey Tanıtım Formu ve TCRTÖ doldurtulmuştur. Birinci gruptaki öğrencilere toplumsal cinsiyet eşitliği ile ilgili 14 hafta boyunca haftada iki saat olmak üzere eğitim verilmiş (eğitim grubu), diğer gruptaki öğrencilere ise (eğitim almayan grup) herhangi bir girişimde bulunulmamıştır. On dört hafta boyunca verilen eğitimler araştırmacılar tarafından ve haftada iki saat olacak şekilde verilmiş, cinsiyet eşitliği kavramı, Türkiye'de ve Dünya'da cinsiyet eşitliği, geleneksel toplumsal roller ve etkileyen faktörler, kadının tarihsel süreçteki yeri, toplumsal cinsiyetin eğitim, sağlık, çalışma yaşamına yansımaları ve medya, hukuk, din ve toplumsal cinsiyet ilişkisi konuları yer almıştır. Tüm konuların anlatımı bittikten sonra, tutum değişikliğini değerlendirmek için her iki gruptaki öğrencilere de TCRTÖ tekrar doldurtulmuştur.

\section{Araştırmanın Etik Yönü}

Veriler araştırmanın gerçekleştirildiği üniversitenin Girişimsel Olmayan Klinik Araştırmalar Etik Kurulu'ndan izin alındıktan sonra (Karar no: 201, Tarih: 28/08/2014), katılımcılardan da yazılı onam alınarak, yüz yüze görüşme tekniği ile 10-15 dakikalık süre içerisinde toplanmıştır.

\section{Verilerin Değerlendirilmesi}

Verilerin analizinde SPSS programının 21.0 versiyonu kullanılmıştır. Öğrencilerin sosyodemografik özellikleri say1, yüzde ve ortalama olarak verilmiştir. Eğitim alan ve eğitim almayan gruplardaki öğrencilerin birinci ve ikinci izlemlerdeki TCRTÖ puan ortalamalarının karşılaştırılması, grupların normal dağılım göstermemesi ve parametrik test varsayımları yerine getirelemediği için Mann Whitney U ve Wilcoxon Testi ile yapılmıştır. TCRTÖ’nden alınan puanların demografik özelliklere göre anlamlı fark gösterip göstermediğini belirlemek amacı ile iki grubun ortalamalarının karşılaştırılmasında Mann-Whitney U testi, üç veya daha fazla grubun ortalamalarının karşılaştırılmasında Kruskal-Wallis testi kullanılmıştır. Sonuçlar \%95 güven aralığında, istatistiksel anlamlılık $\mathrm{p}<0.05$ düzeyinde değerlendirilmiştir.

\section{Araştırmanın Sınırlııkları}

Araştırma, bir hemşirelik bölümünde Toplumsal Cinsiyet Eşitliği dersi alan dördüncü sınıf öğrencileri ile sınırlıdır. Tüm öğrencilere genellenemez.

\section{BULGULAR}

Eğitim alan ve eğitim almayan grupların demografik özelliklerine ilişkin verileri Tablo 1'de yer almaktadır. 
Eğitim alan gruptaki öğrencilerin yaş ortalaması $22.25 \pm 0.81$ olup, \%65.9'u kadın, \%88.6's1 çekirdek aile yapısına sahip, \%72.7'sinin annesi ilköğretim ve altı mezunu, \%54.5'inin babası ilköğretim ve altı mezunu, \%52.3'ü yurtta kalmakta ve \%68.2'sinin en uzun süre yaşadığ1 yer ilçedir. Eğitim almayan gruptaki öğrencilerin ise yaş ortalaması $22.02 \pm 0.89$ olup, $\% 65$ ' $\mathrm{i}$ kadın, \%82.5'i çekirdek aile yapısına sahip, \%72.5'inin annesi ilköğretim ve altı mezunu ve \%57.5' inin babası ilköğretim ve altı mezunu, \%42.5'i evde arkadaşları ile kalmakta ve \%55'inin en uzun süre yaşadığ 1 yer ildir. Öğrencilerin yaş ortalamaları $(\mathrm{F}=1.469, \mathrm{p}=.229)$, cinsiyetleri $\left(\mathrm{x}^{2}=0.008, \mathrm{p}=.930\right)$, aile tipleri $\left(\mathrm{x}^{2}=0.644\right.$, $\mathrm{p}=.422)$, anne $\left(\mathrm{x}^{2}=0.001, \mathrm{p}=.981\right)$ ve baba $\left(\mathrm{x}^{2}=0.432\right.$, $\mathrm{p}=0.806$ ) eğitim durumları ve şu anda yaşadıkları yere $\left(x^{2}=5.664, p=.59\right)$ göre gruplar arasinda fark bulunmazken en uzun süre yaşadıkları yere $\left(\mathrm{x}^{2}=4.598\right.$, $\mathrm{p}=.032$ ) göre fark olduğu belirlenmiştir (Tablo 1).

Eğitim grubundaki ve eğitim almayan gruptaki öğrencilerin eğitim öncesi ve sonrası TCRTÖ puan ortalamalarının karşılaştırılması Tablo 2'de verilmektedir. Eğitim grubundaki öğrencilerin birinci izlemdeki TCRTÖ puan ortalamas1 105.52 \pm 9.64 , ikinci izlemde ise $114.52 \pm 15.99$ 'dur ve aradaki farkın istatistiksel olarak anlamlı olduğu belirlenmiştir $(z=7.049, p=.008)$. Eğitim almayan grupta ise birinci izlemdeki TCRTÖ puan ortalaması 103.42 \pm 9.12 , ikinci izlemde $103.77 \pm 11.46$ olarak belirlenmiş ve puanlar arasında istatistiksel olarak fark olmadığı saptanmıştır ( $\mathrm{z}=0.676, \mathrm{p}=.411)$. Çalışmada eğitim alan ve almayan gruptaki öğrencilerin birinci izlemde TCRTÖ puan ortalamaları arasında fark bulunmazken (MU=774.000, p=.342), eğitim sonrasında yapılan ikinci izlemde eğitim alan gruptaki öğrencilerin almayanlara göre TCRTÖ puan ortalama-
Tablo 1. Öğrencilerin Sosyo-Demografik Özellikleri

\begin{tabular}{|c|c|c|c|}
\hline \multicolumn{2}{|c|}{ Değişkenler } & $\begin{array}{l}\text { Eğitim } \\
\text { Grubu } \\
(n=44)\end{array}$ & $\begin{array}{c}\text { Eğitim } \\
\text { Almayan } \\
\text { Grup }(n=40)\end{array}$ \\
\hline \multicolumn{2}{|c|}{ Yaş (Ort \pm SD) } & $\begin{array}{c}22.25 \pm 0.81 \\
(21-24)\end{array}$ & $\begin{array}{c}22.02 \pm 0.89 \\
(21-25)\end{array}$ \\
\hline \multicolumn{2}{|l|}{$\mathrm{F} / \mathrm{p}$} & \multicolumn{2}{|c|}{$1.469 / 0.229$} \\
\hline \multirow[t]{3}{*}{ Cinsiyet } & Kadın & $29(65.9)$ & $26(65.0)$ \\
\hline & Erkek & $15(34.1)$ & $14(35.0)$ \\
\hline & $x^{2} / p$ & \multicolumn{2}{|c|}{$0.008 / .930$} \\
\hline \multirow[t]{3}{*}{ Aile Tipi } & Çekirdek aile & $39(88.6)$ & $33(82.5)$ \\
\hline & Geniş aile & $5(11.4)$ & $7(17.5)$ \\
\hline & $x^{2} / p$ & \multicolumn{2}{|c|}{$0.644 / .422$} \\
\hline \multirow{3}{*}{$\begin{array}{l}\text { Anne } \\
\text { Eğitim } \\
\text { Durumu }\end{array}$} & $\begin{array}{l}\text { İlköğretim ve } \\
\text { altı }\end{array}$ & $32(72.7)$ & $29(72.5)$ \\
\hline & $\begin{array}{l}\text { Orta öğretim } \\
\text { mezunu }\end{array}$ & $12(27.3)$ & $11(27.5)$ \\
\hline & $x^{2} / p$ & \multicolumn{2}{|c|}{$0.001 / .981$} \\
\hline \multirow{4}{*}{$\begin{array}{l}\text { Baba } \\
\text { Eğitim } \\
\text { Durumu }\end{array}$} & $\begin{array}{l}\text { İlköğretim ve } \\
\text { alt1 }\end{array}$ & $24(54.5)$ & $23(57.5)$ \\
\hline & $\begin{array}{l}\text { Orta öğretim } \\
\text { mezunu }\end{array}$ & $9(20.5)$ & $6(15.0)$ \\
\hline & $\begin{array}{l}\text { Yükseköğretim } \\
\text { mezunu }\end{array}$ & $11(25.0)$ & $11(27.5)$ \\
\hline & $\mathrm{x}^{2} / \mathrm{p}$ & \multicolumn{2}{|c|}{$0.432 / .806$} \\
\hline \multirow{4}{*}{$\begin{array}{l}\text { Şuanda } \\
\text { Yaşadığı } \\
\text { Yer }\end{array}$} & Yurt & $23(52.3)$ & $11(27.5)$ \\
\hline & Evde (aile ile) & 7 (15.9) & $12(30.0)$ \\
\hline & $\begin{array}{l}\text { Evde } \\
\text { (arkadaşlar ile) }\end{array}$ & $14(31.8)$ & $17(42.5)$ \\
\hline & $\mathrm{x}^{2} / \mathrm{p}$ & \multicolumn{2}{|c|}{$5.664 / .59$} \\
\hline \multirow{3}{*}{$\begin{array}{l}\text { En Uzun } \\
\text { Süre } \\
\text { Yaşadığı } \\
\text { Yer }\end{array}$} & İl & $14(31.8)$ & $22(55.0)$ \\
\hline & İlçe & $30(68.2)$ & $18(45.0)$ \\
\hline & $\mathrm{x}^{2} / \mathrm{p}$ & \multicolumn{2}{|c|}{$4.598 / .032$} \\
\hline
\end{tabular}

larının daha yüksek olduğu ve gruplar arasındaki puan farkının da istatistiksel olarak anlamlı olduğu belirlenmiştir (MU=549.000, p=.003) (Tablo 2).

Tablo 2. Öğrencilerin TCRTÖ Puan Ortalamaları

\begin{tabular}{|l|c|c|c|c|}
\hline TCRTÖ Puan Ortalaması & Eğitim Grubu (n=44) & Eğitim Almayan Grup (n=40) & MU & p \\
\hline Birinci İzlem & $105.52 \pm 9.64$ & $103.42 \pm 9.12$ & 774.000 & .342 \\
\hline İkinci İzlem & $114.52 \pm 15.99$ & $103.77 \pm 11.46$ & 549.000 & .003 \\
\hline $\mathbf{z}$ & 7.049 & .676 & & \\
\hline $\mathbf{p}$ & 0.008 & .411 & \\
\hline
\end{tabular}


Eğitim alan ve almayan gruplardaki öğrencilerin cinsiyeti, aile tipi, şu anda yaşadığı yer ve en uzun süre yaşadığı yere göre birinci ve ikinci izlemlerindeki TCRTÖ puan ortalamaları arasında istatistiksel olarak anlamlı düzeyde bir fark bulunamamıştır. Eğitim alan öğrencilerin annelerinin eğitim durumlarına göre ikinci izlemde TCRTÖ puan ortalamaları arasında istatistiksel olarak anlamlı fark olduğu belirlenmiştir (MU=291.000, p=.008). Eğitim alan gruptaki öğrencilerin babalarının eğitim durumlarına göre hem birinci (KW=6.117, $\mathrm{p}=.047$ ) hem de ikinci izlemde $(\mathrm{KW}=7.683, \mathrm{p}=.021)$ TCRTÖ puan ortalamaları arasinda istatistiksel olarak anlamlı fark olduğu, bu farkın da yükseköğretim mezunu olan babalardan kaynaklandığg belirlenmiştir (Tablo 3).

\section{TARTIŞMA}

Toplumsal cinsiyet rolleri, kültürel beklentileri de içeren, kadınlığın ve erkekliğin sosyal ortamlarda ifade edilişidir ve ifade eder. Kadının toplumsal statüsünün yükseltilmesi, kadın ve erkekler arasında eşitliğin sağlanması için, toplumsal cinsiyet rollerine ilişkin bilinçlendirilmesi ve duyarlılık kazandırılması önemlidir. Üniversite düzeyinde eğitime sahip olan bireyler, toplumsal cinsiyet rollerine çağdaş bakış açısına sahip ve daha eşitlikçi bireylerdir (Kahraman ve ark. 2014; Vefikuluçay

Tablo 3. Öğrencilerin Demografik Özelliklerine Göre TCRTÖ Puan Ortalamaları

\begin{tabular}{|c|c|c|c|c|}
\hline \multirow[t]{2}{*}{ Değişkenler } & \multicolumn{2}{|c|}{ Eğitim Grubu $(n=44)$} & \multicolumn{2}{|c|}{ Eğitim Almayan Grup $(n=40)$} \\
\hline & $\begin{array}{c}\text { Birinci İzlem } \\
\text { Ort } \pm \text { SS }\end{array}$ & $\begin{array}{c}\text { İkinci İzlem } \\
\text { Ort } \pm \text { SS }\end{array}$ & $\begin{array}{c}\text { Birinci İzlem } \\
\text { Ort } \pm \text { SS }\end{array}$ & $\begin{array}{l}\text { İkinci İzlem } \\
\text { Ort } \pm \text { SS }\end{array}$ \\
\hline $\begin{array}{l}\text { Cinsiyet } \\
\text { Kadın } \\
\text { Erkek } \\
\text { MU } \\
\text { p }\end{array}$ & $\begin{array}{c}105.51 \pm 9.08 \\
105.53 \pm 10.97 \\
222.000 \\
.911\end{array}$ & $\begin{array}{c}117.00 \pm 16.77 \\
109.73 \pm 13.63 \\
167.500 \\
.215\end{array}$ & $\begin{array}{c}103.69 \pm 8.63 \\
102.92 \pm 10.29 \\
171.500 \\
.769\end{array}$ & $\begin{array}{c}103.42 \pm 10.58 \\
104.42 \pm 13.34 \\
164.000 \\
.624\end{array}$ \\
\hline $\begin{array}{l}\text { Aile Tipi } \\
\text { Çekirdek aile } \\
\text { Geniş aile } \\
\text { MU } \\
\text { p }\end{array}$ & $\begin{array}{c}104.87 \pm 9.42 \\
110.60 \pm 10.96 \\
129.000 \\
.260\end{array}$ & $\begin{array}{c}114.84 \pm 16.83 \\
112.00 \pm 6.89 \\
105.000 \\
.802\end{array}$ & $\begin{array}{c}103.00 \pm 9.59 \\
105.42 \pm 6.67 \\
143.500 \\
.326\end{array}$ & $\begin{array}{c}102.54 \pm 11.38 \\
109.57 \pm 10.75 \\
151.000 \\
.218\end{array}$ \\
\hline $\begin{array}{l}\text { Anne Eğitim Durumu } \\
\text { İlköğretim ve altı } \\
\text { Ortaöğretim mezunu } \\
\text { MU } \\
\text { p }\end{array}$ & $\begin{array}{c}106.59 \pm 9.25 \\
102.66 \pm 10.49 \\
122.500 \\
.067\end{array}$ & $\begin{array}{c}110.62 \pm 14.99 \\
124.91 \pm 14.29 \\
291.000 \\
.008\end{array}$ & $\begin{array}{c}103.93 \pm 8.49 \\
102.09 \pm 10.95 \\
139.500 \\
.550\end{array}$ & $\begin{array}{c}105.20 \pm 12.33 \\
100.00 \pm 8.03 \\
105.000 \\
.103\end{array}$ \\
\hline $\begin{array}{l}\text { Baba Eğitim Durumu } \\
\text { İlköğretim ve altı } \\
\text { Ortaögretim mezunu } \\
\text { Yükseköğretim mezunu } \\
\text { KW } \\
\text { p }\end{array}$ & $\begin{array}{c}102.63 \pm 11.09 \\
102.22 \pm 9.27 \\
108.08 \pm 8.68 \\
6.117 \\
.047\end{array}$ & $\begin{array}{c}112.75 \pm 15.73 \\
105.00 \pm 10.17 \\
126.18 \pm 14.45 \\
7.683 \\
.021\end{array}$ & $\begin{array}{c}101.43 \pm 6.90 \\
107.50 \pm 8.33 \\
105.36 \pm 12.72 \\
2.706 \\
.259 \\
\end{array}$ & $\begin{array}{c}102.86 \pm 11.94 \\
102.33 \pm 7.14 \\
106.45 \pm 12.72 \\
0.690 \\
.708\end{array}$ \\
\hline $\begin{array}{l}\text { Şu Anda Yaşadığı Yer } \\
\text { Yurtta } \\
\text { Evde (aile ile) } \\
\text { Evde (arkadaşlar ile) } \\
\text { KW } \\
\text { p }\end{array}$ & $\begin{array}{c}107.00 \pm 10.44 \\
101.57 \pm 6.99 \\
105.07 \pm 9.37 \\
2.457 \\
.293\end{array}$ & $\begin{array}{c}116.21 \pm 18.42 \\
114.14 \pm 14.21 \\
111.92 \pm 12.88 \\
0.492 \\
.782\end{array}$ & $\begin{array}{c}99.27 \pm 8.79 \\
101.91 \pm 6.57 \\
107.17 \pm 9.81 \\
4.286 \\
.117 \\
\end{array}$ & $\begin{array}{c}103.63 \pm 10.08 \\
102.75 \pm 10.48 \\
104.58 \pm 13.40 \\
0.302 \\
.860\end{array}$ \\
\hline $\begin{array}{l}\text { En Uzun Süre Yaşadığı Yer } \\
\text { İl } \\
\text { İlçe } \\
\text { MU } \\
\text { p }\end{array}$ & $\begin{array}{c}108.28 \pm 9.08 \\
104.23 \pm 9.77 \\
159.000 \\
.198\end{array}$ & $\begin{array}{c}119.50 \pm 15.09 \\
112.20 \pm 16.11 \\
149.000 \\
.123\end{array}$ & $\begin{array}{c}103.13 \pm 9.97 \\
103.77 \pm 8.24 \\
208.000 \\
.798\end{array}$ & $\begin{array}{c}103.40 \pm 11.64 \\
104.22 \pm 11.55 \\
230.000 \\
.396\end{array}$ \\
\hline
\end{tabular}


ve ark. 2007; Y1lmaz ve ark. 2009). Mezun olduklarında toplumda en fazla değişimi yaratabilecek olan üniversite öğrencilerine, eğitimleri sırasında temel mesleki bilginin yanında toplumsal cinsiyet eşitliği konusunda duyarlılık ve bilincin de kazandırılması gerekmektedir. Planlı eğitimin üniversite öğrencilerinin toplumsal cinsiyet rollerine ilişkin tutumları üzerine etkisini değerlendirmeyi amaçlayan bu çalışmada, eğitim alan ve almayan gruptaki öğrencilerin, eğitim sonrasında yapılan ikinci izlemlerinde TCRTÖ puanları arasındaki farkın istatistiksel olarak anlamlı olduğu belirlenmiştir. Literatürde genellikle lise ve üniversite öğrencilerinin toplumsal cinsiyet rollerine ilişkin görüşlerinin belirlenmesine yönelik ülkemizin farklı bölgelerinde yapılmış çok sayıda çalışma olmasına rağmen, toplumsal cinsiyet eşitliği eğitiminin etkinliğini belirleyen tek bir çalışma yer almaktadır. Aksan ve ark. (2011) tarafından İzmir'de müfredata eklenen bir dersin üniversite öğrencilerinin kadına yönelik şiddetle ilgili bilgi ve tutumlarına etkilerini değerlendirmek amacıyla yapılan çalışmada, toplumsal cinsiyet rolleri de incelenmiştir. Öğrencilerin eğitim sonrasında toplumsal cinsiyet rollerine ilişkin tutumlarının daha olumlu olduğu bildirilmiştir.

Üniversiteler toplumun gelişimi ve dönüşümüne öncülük eden temel kurumlardır ve bu kurumlarda toplumsal cinsiyet eşitsizliğinin farkına varılarak, önlenmesini sağlayacak eğitimlerin verilmesi önemlidir. Kadına yönelik şiddetin ve istismarın önlenmesi amacıyla Yükseköğretim Kurulu, 7 Mayıs 2015 tarihinde yaklaşık 70 üniversitenin Kadın Sorunları Araștırma ve Uygulama Merkezi Başkanlarının, konu ile ilgili akademisyenlerin, kadın çalışmaları yapan sivil toplum kuruluşları ve ilgili sendika temsilcilerinin katılımı ile bir çalıştay gerçekleștirmiștir. Çalıştayda; a) Toplumsal Cinsiyet Eşitliği dersinin zorunlu olarak müfredata eklenmesi, b) Üniversite ortamında şiddet, cinsel taciz, istismar ve mobbing, c) Üniversitelerde toplumsal cinsiyet eşitliğinin genel kabul görmesinin sağlanması, d) Üniversitelerin yöneticilerine idari ve akademik personeline toplumsal cinsiyet eşitliği farkındalığının kazandırılması temaları üzerinde durulmuştur. Toplumsal Cinsiyet Eşitliğine Duyarlı Üniversite Çalıştayı sonuç raporuna göre Yükseköğretim Kurulu'nun 28 Mayıs 2015 tarihli genel kurul toplantısında "Toplumsal Cinsiyet Eşitliğii" dersinin yükseköğretim programlarında üniversitelerde zorunlu veya seçmeli ders olarak yer almasına karar verilmiştir (YÖK Genel Kurul Kararı 2015).

Çalışmada her iki gruptaki öğrencilerin eğitim öncesi ve sonrası cinsiyet, aile tipi, şu anda yaşadığı yer ve en uzun süre yaşadığı yerin toplumsal cinsiyet rollerine ilişkin algılarını etkilemediği belirlenmiştir. Yılmaz ve ark. (2009) tarafindan Ankara'da, Vefikuluçay ve ark. (2007) tarafından Kars’ta, Öngen ve Aytaç (2013) tarafindan TCRTÖ kullanılarak Bursa'da ve Pınar ve ark. (2008) tarafindan Ankara'da öğrencilerin toplumsal cinsiyet rol kalıplarına ilişkin tutumlarının belirlenmesi amacıyla yapılan çalışmalarda kız öğrencilerin erkek öğrencilerden daha fazla kadın ve erkeğin toplum içinde eşitlikçi role sahip olduğu, erkeklerin ise daha gelenekçi tutum içinde oldukları sonucu elde edilmiştir. Altuntaş ve Altınova (2015) tarafından Ankara'nın sosyoekonomik düzey bakımından üç farklı ilçesinde yaşayan, toplumsal cinsiyet algılarını değerlendirmek amaciyla ortaöğretimde eğitim gören öğrencilerin velileri ile yapılan çalışmada erkeklerin kadınlara göre daha geleneksel cinsiyet rollerine sahip oldukları belirlenmiştir. Bu çalışmada da öğrencilerin cinsiyetlerinin toplumsal cinsiyet rollerine ilişkin algılarını etkilemediği belirlenmiştir. Planlı eğitim, kız öğrencilerin toplumsal cinsiyet rollerine ilişkin tutumlarında değişiklik yaratmada etkili iken, erkek öğrencilerde değişim yaratma konusunda yeterli olamamıştır. Erkeklerin kız öğrencilere göre daha geleneksel toplumsal cinsiyet rolleri kalıp yargılarına sahip olmalarının, bu yargıların kendi yararlarına olmasina ve bu durumun toplum tarafindan destek görmesine bağlı olabileceği düşünülmektedir.

Çalışmada eğitim grubundaki öğrencilerin, anne babalarının eğitim durumlarının toplumsal cinsiyet algıları üzerine olumlu etkilerinin olduğu belirlenmiştir. Altuntaş ve Altınova (2015)'nın çalışmasında da eğitim durumu üniversite olan kadın ve erkeklerin daha eşitlikçi tutum içinde oldukları belirlenmiştir. Aksan ve ark. (2011) çalışmasında da anne eğitim durumunun artmasının toplumsal cinsiyet rollerine ilişkin tutumu olumlu 
etkilediği bulunmuştur. Kız ve erkek çocuklarının karş1 cinse özgü davranış ve ilgi alanlarına yönelmelerinde, eşitlikçi tutumlara sahip olmalarında ebeveynlerin ve özellikle annenin eğitim düzeyinin artması önemli bir etkiye sahiptir.

\section{SONUÇ VE ÖNERÍLER}

Araştırma sonuçları;

Toplumsal Cinsiyet Eşitliği dersi alan öğrencilerin almayan öğrencilere göre TCRTÖ puan ortalamalarının arttı̆̆1$\mathrm{n} 1$ ve aradaki farkın istatistiksel olarak anlamlı olduğunu,

Eğitim grubundaki, annesi ortaöğretim mezunu olan öğrencilerin ikinci izlemde ve babası yükseköğretim mezunu olan öğrencilerin hem birinci hem de ikinci izlemde TCRTÖ puan ortalamalarının istatistiksel olarak anlamlı bir şekilde daha yüksek olduğunu göstermiştir.

Çalışmadan elde edilen bulgulara göre;

Tüm Türkiye'de yükseköğretim programlarında Toplumsal Cinsiyet Eşitliği dersine yer verilmesi,

Ders içeriklerinde tek bir çekirdek program oluşturulmas1 ve

Benzer araştırmaların daha büyük örneklem grupları ile planlanması önerilmektedir.

\section{KAYNAKLAR}

Akın, A., Demirel, S. (2003). Toplumsal cinsiyet kavramı ve sağlığa etkileri. Cumhuriyet Üniversitesi Tip Fakültesi Dergisi, Halk Sağlı̆̆ı Özel Eki, 25(4): 73-82.

Aksan, H. A. D., Ergin, I., Hassoy, H., Durusoy, R., Çiçeklioğlu, M. (2011). Müfredata eklenen bir dersin ikinci snnıf tıp ögrencilerinin kadına yönelik şiddetle ilgili bilgi ve tutumlarına etkilerinin değerlendirilmesi. Türkiye Halk Sağlı̆̆ Dergisi, 9(3): 144-156.

Altuntaş, O., Altınova, H. H. (2015). Toplumsal cinsiyet algısı ile sosyo-ekonomik değişkenler arasındaki ilişkinin belirlenmesi. International Periodical for the Languages, Literature and History of Turkish or Turkic, 10(6): 83-100.

Atış, F. (2010). Ebelik/ hemşirelik 1. ve 4. sınıf öğrencilerinin toplumsal cinsiyet rollerine ilişsin tutumlarııın belirlenmesi. Yüksek $L i$ sans Tezi, Çukurova Üniversitesi Sağlık Bilimleri Enstitüsü, Adana.

Bhasin, K. (2003). Toplumsal Cinsiyet "Bize Yüklenen Roller". Kadınlarla Dayanışma Vakfı Yayınları, İstanbul.

Demir, Ü. (1999). Kadının toplumsal statüsü. Sağllk ve Toplum Dergisi, 2(1): 12-16.
Dökmen, Z. Y. (2004). Toplumsal Cinsiyet, Sosyal Psikolojik Açılamalar. Sistem Yayıncılık, İstanbul.

Flowers, N. (Ed.) (2009). Compasito Manual on Human Rights Education for Children. 2nd ed., Published by the Directorate of Youth and Sport of the Council of Europe, Hungary.

Kahraman, L. ve ark. (2014). Nevşehir Hacı Bektaş Veli Üniversitesi toplumsal cinsiyet algısı araştırması. International Periodical for the Languages, Literature and History of Turkish or Turkic, 9(2): 811-831.

Keith, B., Jacqueline, S. (2002). Parent and adolescent gender role attitudes in 1990's great Britain. Sex Roles, 46(7/8): 239-244.

Öngen, B., Aytaç, S. (2013). Üniversite öğrencilerinin toplumsal cinsiyet rollerine ilişkin tutumları ve yaşama değerleri ilişkisi. Sosyoloji Konferanslarl, 48: 1-18.

Özcan, A. (2012). Toplumsal cinsiyet eğitiminin üniversite öğrencilerinin toplumsal cinsiyet rol tutumlarına etkisi. Doktora Tezi, Erciyes Üniversitesi Sağlık Bilimleri Enstitüsü, Kayseri.

Özvarış, S. B. (2007). Türkiye'de kadın ve sağlık. Sted Dergisi, 16(3): 7-8.

Özvarış, S. B. (2008). Toplumsal cinsiyet, kadın ve sağlık. Hacettepe Tip Dergisi, 39: 168-174.

Pınar, G., Taşkın, L., Eroğlu, K. (2008). Başkent Üniversitesi öğrenci yurdunda kalan gençlerin toplumsal cinsiyet rol kalıplarına ilişkin tutumları. Hacettepe Üniversitesi Sağlık Bilimleri Fakültesi Hemşirelik Dergisi, 15(1): 47-57.

Sağ, V. (2003). Toplumsal değişim ve eğitim üzerine. Cumhuriyet Üniversitesi Sosyal Bilimler Dergisi, 27(1): 11-25.

Turan, N. ve ark. (2011). Toplumsal cinsiyet ve hemşirelik. Maltepe Üniversitesi Hemşirelik Bilim ve Sanatı Dergisi, 4(1): 167-173.

Vefikuluçay, D., Zeyneloğlu, S., Eroğlu, K., Taşkın, L. (2007). Kafkas Üniversitesi son sınıf ögrencilerinin toplumsal cinsiyet rollerine ilişkin bakış açıları. Hacettepe Üniversitesi Hemşirelik Yüksekokulu Dergisi, 14(2): 12-27.

World Economic Forum the Global Gender Gap Report (2015). World Economic Forum the Global Gender Gap Report, https:// www.weforum.org/reports/global-gender-gap-report-2015 (21.12.2015).

Yılmaz, D. V. ve ark. (2009). Üniversite öğrencilerinin toplumsal cinsiyet rollerine ilişkin görüşleri. Uluslararası İnsan Bilimleri Dergisi, 6(1): 775-792.

Yükseköğretim Kurulu Genel Kurul Kararı (2015). Yükseköğretim Kurulu Genel Kurul Kararı, http://www.yok.gov.tr/documents/18755141/21995128/45_yokten_kadin_calistayi_karari.pdf (20.12.2015).

Zeyneloğlu, S., Terzioğlu, F. (2011). Toplumsal Cinsiyet Rolleri Tutum Ölçeği'nin geliştirilmesi ve psikometrik özellikleri. Hacettepe Üniversitesi Ĕ̆itim Fakültesi Dergisi, 40: 409-420. 